\title{
WYKORZENIENIE I OSADZENIE. DRAMAT ZMIENNYCH GRANIC W POLSKIM TEATRZE WSPÓŁCZESNYM
}

\author{
PIOTR DOBROWOLSKI ${ }^{1}$ \\ (Uniwersytet im. Adama Mickiewicza w Poznaniu)
}

Słowa kluczowe: przeciw-historia, postpamięć, dramat, teatr, performatywność

Key words: anti-history, postmemory, drama, theatre, performativity

\begin{abstract}
Abstrakt: Piotr Dobrowolski, WYKORZENIENIE I OSADZENIE. DRAMAT ZMIENNYCH GRANIC W POLSKIM TEATRZE WSPÓŁCZESNYM. „PORÓWNANIA” 13, 2013, t. XIII, s. 225-237. ISSN 1733-165X. Artykuł opisuje zmiany w sposobie prowadzenia dyskursu w polskiej dramaturgii historycznej ostatnich lat na przykładzie tekstów dotyczących Ziem Odzyskanych. Od niedawna bohaterami spektakli stają się osoby pozostawione na marginesie wielkiej historii. To Niemcy wysiedlani z terenów zajętych przez Polskę, ale także ludność ze Wschodu przesiedlana na te ziemie. Teatr przekazujący doświadczenia wykorzenionych i osadzonych, dając im szansę mówienia własnym głosem, pozwala przełamać „historyczną amnezję" grup wykluczanych i pozbawionych przeszłości. Otwiera tak postkolonialną perspektywę widzenia rodzimej historii. Omówione w artykule teksty i przedstawienia to Niech żyje wojna! Pawła Demirskiego, Transfer! Jana Klaty i wyreżyserowana przez Marcina Libera inscenizacja dramatu Trash Story Magdy Fertacz.
\end{abstract}

Abstract: Piotr Dobrowolski, UPROOTED AND RESETTLED. THE DRAMA OF VARIABLE BORDERS IN THE CONTEMPORARY POLISH THEATER. "PORÓWNANIA" 13, 2013, Vol. XIII, p. 225-237. ISSN 1733-165X. The article describes the changes in discourse in recent Polish historical plays on the basis of texts about the Recovered Territories. The characters in the play are the people left on the margins of great history: the Germans deported from the territories of pre-war Germany that became part of Poland after World War II and the people from the East resettled by the authorities to this land. The theatre that transfers the experience of the uprooted and the resettled gives them the opportunity to speak with their own voice. The theatre breaks the "historical amnesia" of those who used to be excluded and voiceless. It opens a new, postcolonial perspective on Polish history. The discussed texts and plays are Paweł Demirski's Niech żyje wojna! (Long live the war!), Transfer! by Jan Klata and Marcin Liber's staging of Trash Story written by Magda Fertacz.

${ }^{1}$ Correspondence Address: p.dobro@amu.edu.pl 
Fenomen historii tak zwanych „Ziem Odzyskanych”, chociaż może inspirować do prowadzenia dramatycznej, wielowątkowej i wieloaspektowej opowieści, w czasie Polski Ludowej, a także wiele lat później, prezentowany był głównie $\mathrm{z}$ aprobowanej przez władzę perspektywy. A ta, nawet jeśli zmieniała się diametralnie, rzadko dążyła do zmiany obowiązującego modelu narracji. $\mathrm{W}$ teatrze polskim sytuacja zmieniła się około roku 2006, kiedy wśród najważniejszych spektakli sezonu zaczęto wymieniać zrealizowany we Wrocławiu Transfer! Jana Klaty. Dzięki temu przedstawieniu w świadomości wielu osób, nie tylko teatralnych widzów i nie tylko Polaków, powrócił temat powojennych przesiedleń. Odtąd temat wykorzenienia i osadzenia, jako historyczna realizacja prowadzonej z rozmysłem wobec różnych grup społecznych polityka wewnętrzna państwa, pojawia się czasem na polskich scenach. Zwrócenie uwagi pisarzy, autorów filmowych i teatralnych na pomijanych przez lata w polskim dyskursie historycznym Niemców z Pomorza, Ziemi Lubuskiej, Prus i Dolnego Śląska czy ludzi przesiedlonych w ramach akcji "Wisła", jest tylko jednym z przykładów, że w świadomości części polskich artystów budzi się rodzaj świadomości postkolonialnej.

Praktyką realizowaną przez coraz większą liczbę autorów polskich dramatów historycznych jest przełamywanie tendencji tradycyjnie dominujących w rodzimej historiografii i otwieranie przestrzeni pomijanych w dyskursie na temat przeszłości. Zjawisko to postrzegać można jako rodzaj odchodzenia od swoistej „,amnezji historycznej" na korzyść "odzyskiwania" wieloaspektowej historii2. Niektóre publikowane i wystawiane w ostatnich latach teksty teatralne dramatopisarzy takich jak Magda Fertacz (Trash Story), Sylwia Chutnik (Muranooo), Małgorzata SikorskaMiszczuk (Burmistrz), Paweł Demirski (Tykocin, napisany razem z Michałem Zadarą), Bożena Keff (Utwór o matce i ojczyźnie), Julia Holewińska (Ciała obce3) czy Tadeusz Słobodzianek (Nasza klasa) mogą przyczyniać się do częściowego obalania kolejnych "jedynie słusznych" - tworzonych przez dotychczasowe elity (zwykle przyjmujące jednorodną perspektywę państwową, czyli de facto narodową) - wizji czasu minionego, oddając głos grupom zdominowanym ${ }^{4}$. Siła utrwalonych w społecznej świadomości wyobrażeń wynika nie tylko z ich powtarzalności, ale rów-

2 Por. L. Gandhi, Teoria postkolonialna. Wprowadzenie krytyczne. Przeł. J. Serwański. Poznań 2008, s. $16-17$.

${ }^{3}$ Ciała obce Julii Holewińskiej to jedyny w tym zestawieniu dramat nie sięgający do historii zakorzenionych w czasie drugiej wojny światowej, a odnoszący się do czasów zrywu solidarnościowego.

${ }^{4} \mathrm{~W}$ znakomitej większości wymienionych tu tekstów rozbicie centrum dramatycznej narracji i oddanie głosu przedstawicielom grup podlegającym dotychczas dominacji jest rodzajem zabiegu twórczego, który nie ma związku z faktycznym pochodzeniem samych autorów. Wyjątek w tym zbiorze stanowi Bożena Keff, opisująca własne relacje z matką jako uczestniczką represjonującej historii i Tadeusz Słobodzianek, który od początku swojej kariery dramatopisarskiej podkreślał, że urodził się w rodzinie polskich zesłańców w Jenisejsku na Syberii, a po repatriacji dorastał na białostocczyźnie, nawet tam postrzegany częściowo jako obcy. 
nież z poparcia, jakim obdarzają je dominujące $\mathrm{w}$ kraju autorytety i instytucje, których sztandarowym przykładem jest Instytut Pamięci Narodowej. Ogólne dążenie twórców działających $\mathrm{w}$ obszarze teatru do rozbicia monolitu jednoznacznej narracji prezentującej przeszłe zdarzenia nie jest zjawiskiem nowym: wskazać można wiele znakomitych spektakli powstałych w czasach PRL, zwłaszcza autorów takich jak Jerzy Jarocki, Andrzej Wajda, Konrad Swinarski czy Jerzy Grzegorzewski ${ }^{5}$, którzy prowadzili - z oczywistych przyczyn nie zawsze jawną i często nie wprost - polemikę z zastanym i promowanym przez władzę obrazem minionych zdarzeń. Wybitni reżyserzy stawali w ten sposób w opozycji do dominujących i promowanych w owym czasie wizji przeszłości, równolegle utrwalanych przez instytucje teatralne takie jak Teatr Telewizji z powstałym $\mathrm{w}$ jego ramach cyklem Teatr Faktu TV (1963-1980) i znakomita większość podlegających cenzurze i programowej polityce kulturalnej instytucjonalnych teatrów repertuarowych.

Ścisłe powiązanie rozpowszechnianej wizji historii z założeniami polityki prowadzonej przez totalitarną władzę czasów Polski Ludowej w ramach tworzonej sztuki doprowadziło $\mathrm{w}$ ówczesnych opowieściach, narracjach i dramatach do marginalizacji różnego rodzaju Innych, nie pasujących do wizji jednorodnego państwa narodowego. Nieobecnym (wymordowani lub zmuszeni do emigracji Żydzi i Romowie), zwyciężonym podczas drugiej wojny światowej (mieszkańcy Prus Wschodnich i pozostali obywatele III Rzeszy, żyjący na terenach dawnych kresów niemieckich postrzegani przez pryzmat zbiorowej odpowiedzialności jako jednoznacznie winni wojennej zbrodni Niemcy) czy marginalizowanym po niej grupom etnicznym i narodowym (Ślązacy, Kaszubi), a także pozbawionym swoich miejsc na ziemi mniejszościom (Łemkowie, Bojkowie, Dolinianie czy przesiedleni na Zachód Ukraińcy) ostatecznie odebrane zostało prawo głosu, który nigdy wcześniej nie był w pełni równouprawniony ani wystarczająco respektowany.

W pierwszych latach istnienia Polski Ludowej, w do niedawna niemieckich miastach, odbyło się fizyczne i symboliczne przejęcie istniejących tam wcześniej teatrów i zakładanie nowych scen: W 1946 roku powstał Teatr Polski w Szczecinie,

5 Wiele z pamiętanych do dzisiaj doniosłych spektakli obnażających w czasach PRL mechanizmy pamięci Polaków wystawionych zostało w Starym Teatrze w Krakowie. Fenomen tej sceny opisała niedawno Anna R. Burzyńska, zwracając uwagę również na ten aspekt jej historii. Powołując się na obserwacje Małgorzaty Dziewulskiej wspomina o Biesach (1971) według Fiodora Dostojewskiego i Emigrantach (1976) Sławomira Mrożka w reżyserii Andrzeja Wajdy - spektaklu zagranym dwieście dziewięćdziesiąt dwa razy (...)”, o „Wiśniowym sadzie (1975) i Śnie o Bezgrzesznej (1979) Jerzego Jareckiego, wreszcie o „Weselu (1977) w reżyserii Jerzego Grzegorzewskiego”. Stwierdza: „We wszystkich tych spektaklach historia wdzierała się $\mathrm{w}$ to, co indywidualne, prywatność nie stanowiła żadnego azylu przed traumami przeszłości. Różne płaszczyzny czasowe i przestrzenne łączyła jednostkowa i zbiorowa pamięć, manifestująca się w śladach, resztkach. Dokonywała się nieustająca praca świadomości: od realnego do symbolicznego i z powrotem”. A. R. Burzyńska, Tradycja i profanacja. „Dialog” 2012, nr 12, s. 54. 
Teatr Miejski im. Józefa Korzeniowskiego w Gorzowie Wielkopolskim (obecnie im. Juliusza Osterwy) i Teatr Miejski (dziś Teatr Polski), rok wcześniej zainicjowano powołanie Teatru Miejskiego w Zielonej Górze (dziś Lubuski Teatr im. Leona Kruczkowskiego), choć do pierwszej premiery doszło tam dopiero w roku 1951. Działalność tych instytucji inicjowano zwykle wystawiając sztuki Aleksandra Fredry (Damy i Huzary w reżyserii Bronisława Skąpskiego w Szczecinie, Śluby panieńskie w reżyserii Teofila Trzcińskiego we Wrocławiu i Zemstę w reżyserii Róży GelliCzerskiej w Zielonej Górze; w Gorzowie Wielkopolskim wystawiono Starego kawalera Józefa Korzeniowskiego, reż. Henryk Barwiński). W ten sposób również teatr przyczyniał się do potwierdzania proklamowanej polskości przejętych ziem, wraz z innymi dziedzinami kultury dążąc do promocji wprowadzanego przez władzę określenia "Ziemie Odzyskane” i propagandowego sloganu mówiącego o „powrocie ziem północnych i zachodnich do macierzy".

Po roku 1989 musiało upłynąć jeszcze kilkanaście lat, żeby w obszarze twórczości artystycznej widzianej na tle utwierdzonych zależności i historycznej dominacji coś się zmieniło. Początkowo bowiem wspomniani Inni pojawiali się w opowieściach dotyczących powracających z niebytu czasów Polski Ludowej zdarzeń jedynie czasem, zwykle jako pozbawione własnego głosu cienie przeszłości, mające jedynie wywoływać nostalgię za tym, co minione. I chociaż już na samym początku lat dziewięćdziesiątych możliwe były i w różnych miejscach dzisiejszej Polski zachodniej niejednokrotnie pojawiały się akcenty pozwalające na zaznaczenie etnicznej różnorodności w historii tych terenów, ich znaczenie nie przekraczało wymiaru lokalnego. Wymienić można między innymi rozwijającą się dzisiaj współpracę teatrów ze Szczecina i Zielonej Góry ze scenami niemieckimi, organizowany $\mathrm{w}$ północnej Wielkopolsce, a nawiązujący do kultury przesiedlonych mniejszości, festiwal folklorystyczny Bukowińskie Spotkania czy powstały w Katowicach w 1990 śląski teatr Korez. Przez kolejne lata bardzo niewiele informacji na temat tego typu inicjatyw docierało jednak do kulturalnego mainstreamu. Niezależnie od politycznego przełomu, manifestowanej wolności i odstąpienia od kontroli prasy, widowisk i innej twórczości artystycznej, nadal istniało zjawisko marginalizacji grup zdominowanych po drugiej wojnie światowej. $W$ polskim teatrze nie pojawiały się również spektakle zdolne wpływać na ustalone schematy myślenia historycznego i zmieniające utrwalone podejście do historii. Zmieniła się oczywiście perspektywa widzenia wielu zdarzeń znanych z przeszłości, ale zmiana ta jedynie odwracała wektory opisu problemów, zachowując zastane zależności i niemal nie poszerzając repertuaru punktów widzenia. $W$ rezultacie, marginalizowani w opowieściach, narracjach i dramatach czasów PRL Inni, nadal nie zyskali prawa głosu.

Do utrzymania takiego stanu rzeczy, niczym rodzaj niezamierzonej "grubej kreski", odkreślającej część dawnych, a wciąż jątrzących się w świadomości mniejszości problemów, przyczyniła się twórcza tendencja realizacji postulatów doma- 
gających się portretowania nowej rzeczywistości politycznej, społecznej i ekonomicznej. Podnoszono je wielokrotnie przez kilkanaście kolejnych lat po roku 1989. Praktyka wyznaczania nowych konwencji realistycznych sprawiła, że w tym czasie na scenach teatrów repertuarowych niemal nie pojawiał się temat mechanizmów pamięci i weryfikacji utartych schematów myślenia i ustalonego postrzegania zjawisk historycznych, zgodnego z dominującą perspektywą władzy. Obecne w ówczesnej twórczości wątki dotyczące dominacji, podległości i ich historycznego tła rzadko były propozycjami otwierającymi dyskurs; ich celem nadal pozostawało potwierdzanie obowiązującego modelu narracji historycznej. Dobitnym przykładem tej tendencji było powołanie przez TVP Sceny Faktu, cyklu, który w kolejnych latach zwiększał swoje znaczenie w repertuarze Teatru TVP.

A jednak na początku sezonu 2006/2007, w tym samym czasie, kiedy inicjowano działalność Sceny Faktu, zaczęto także wystawiać pierwsze po politycznym przełomie w Polsce spektakle teatralne, które uzupełniały, a czasem nawet polemizowały z promowaną środkami IPN wizją przeszłości. Dzisiaj wydaje się, że to właśnie otwarcie nowego rozdziału łączącego kulturę i politykę historyczną państwa, sprowokowało reakcję twórców i wpłynęło na poszerzenie prezentowanych przez nich perspektyw widzenia zjawisk. Świadomie starali się zatem przyciągać uwagę widzów i zachęcać ich do dyskusji, dążąc do otwarcia dyskursu nie tylko wobec demograficznej zmienności i historii, ale także $w$ odniesieniu do praktyki historiograficznej. Jednym z pierwszych przykładów takiego działania w ramach sztuki scenicznej był głośny Transfer! Jana Klaty, wystawiony w Teatrze Współczesnym we Wrocławiu (premiera 18.11.2006). Wspomniana tendencja polemiczna, którą część komentatorów dostrzegała w tym spektaklu, określana była przez niektórych z nich jako „populizm historyczny”, mający być sposobem "zakłamywania historii" czy teatralnego "fałszu"7. Inni uważają ją za świadectwo dojrzałości nieobciążonego traumą wojny (i jej peerelowskiej wizji) pokolenia, które zaczęło właśnie mówić we własnym imieniu, dążąc przy tym do „odkłamywania historii" 8 . W różnych wariantach praktyka ta opisywana jest także z użyciem innych, funkcjonujących równolegle określeń, które podkreślają wybrane jej cechy: Weronika Szczawińska w wywiadzie z Joanną Tokarską-Bakir nazywa ją „zwrotem

${ }^{6}$ J. Sieradzki, Pułapki przesiedleń. „Przekrój” 12.12.2006, nr 49.

7 M. Hałas, Znak równości. „Gazeta Polska” 12.04.2007, nr 15.

${ }^{8} \mathrm{~W}$ takim duchu, choć nie używając pojęcia "odkłamywania historii", wypowiedzieli się o Transferze! na przykład Rafał Węgrzyniak (R. Węgrzyniak, Seans pamięci wypędzonych. „Odra” 2007, nr 1) i Justyna Golińska (J. Golińska, Historia nasza i wasza. „Dialog” 2007, nr 6), a Aneta Kyzioł stwierdziła, że spektakl ten to „przejmujące świadectwo czasu, w którym historia oszalała” (A. Kyzioł, Z perspektywy Obcego. „Polityka” 2006, nr 47). Równocześnie pojęcie „odkłamywania historii” pojawiało się w słowniku publicystyki prawicowej, opisującej Scenę Faktu TVP. Użycie tego zwrotu określiło także założenia ówczesnego kierownictwa Teatru Telewizji: „Gdy w 2006 r. Wanda Zwinogrodzka została kierownikiem artystycznym Teatru Telewizji, tworząc Scenę Faktu, za priorytet uznała odkłamywanie historii” (S. Krasnodębska, Oddając hołd bohaterskiej „Ince”. „Gazeta Polska Codziennie” 2013, nr 441, s. 9). 
pamięciowym, antyamnezyjnym" 9 , redaktorzy wydanej w końcu zeszłego roku pierwszej monografii poświęconej tej problematyce mówią o „złej pamięci” - która jest nie tylko formą niepamiętania, ale także sugestią dysfunkcji i deformacji pamięci (w domyśle - domagającą się przełamania). Badacze zgadzający się z koncepcją Michaela Foucaulta i opisujący trend dążący do wskazywania w dramacie i z teatralnej sceny wszystkiego tego, co niegdyś zostało „starannie, z rozmysłem, złośliwie przeinaczone i zamaskowane" 10 mówią zaś o przeciw-historii.

Po otwarciu zainicjowanym $\mathrm{w}$ połowie pierwszej dekady XXI wieku w polskim dramacie i na teatralnych scenach naszych teatrów znaleźć można obecnie różnorodne przykłady tematyzowania i polemicznego wykorzystania dyskursu historycznego. Reżyserzy i autorzy prowokują, ale rzadko oskarżają kogokolwiek, łącząc w swoich artystycznych wypowiedziach problemy władzy, podległości, polityki i podważając autorytet utwierdzonej narracji o nich. Coraz częściej pojawiają się także teksty i spektakle, które "dopuszczają do głosu ofiary wykluczone z dziejów spisanych przez zwycięzców" ${ }^{\prime 1}$, zbliżając się do postkolonialnej praktyki oddawania głosu klasom podrzędnym. Nietrwałość sprawowanej władzy i obserwacja granic, przemieszczających się $\mathrm{w}$ wyniku zmieniających się frontów wojennych, odgórnych ustaleń i aliansów rządzących zachęca do spojrzenia na wielką historię $\mathrm{z}$ lokalnej perspektywy marginalizowanych jednostek i grup społecznych. Zmiany takich zależności opisane zostały przez Tadeusza Słobodzianka na przykładzie okupacyjnych relacji pomiędzy Polakami, Rosjanami, Żydami i Niemcami w powszechnie znanym i szeroko dyskutowanym tekście pt. Nasza klasa. Jego podtytuł: Historia w XIV lekcjach podkreśla zamierzoną przez autora wymowę dydaktyczną, jednak różnorodność prezentowanych perspektyw, bez wskazywania dominującego punktu widzenia, nie niesie niebezpieczeństwa nachalnego nauczania nowej, a jednak nadal „jedynie słusznej”, wersji historii.

Przesuwający się front i wprowadzanie nowej władzy portretowane są także tym razem z perspektywy przemieszczających się żołnierzy - $w$ dramacie Pawła Demirskiego Pt. Niech żyje wojna! Jego bohaterowie, którzy jako członkowie 1 Armii Wojska Polskiego wędrują wraz z postępującymi na zachód oddziałami, wprowadzają na zdobytych ziemiach władzę ludową, jakby realizując $w$ ten sposób spóźnione postulaty utworzonej w 1930 roku Polskiej Ligi Morskiej i Kolonialnej:

żądam żeby armia polska

Poszerzyła zachodnie granice

i żeby zdobyła Berlin

i żeby nic się nie zmieniło. ${ }^{12}$

${ }^{9}$ Z Eryniami w zmowie. Z Joanna Tokarska-Bakir rozmawia Weronika Szczawińska. W: Zła pamięć. Przeciw-historia w polskim teatrze i dramacie. Red. M. Kwaśniewska, G. Niziołek. Wrocław 2012, s. 265.

${ }^{10}$ Cyt. za Zła pamięć, ed. cit., s. 10.

11 Ibidem.

12 P. Demirski, Niech żyje wojna! W: idem, Parafrazy. Warszawa 2011, s. 345. 
Wzorem dla autora były w tym tekście postacie znane z serialu Pt. Czterej pancerni $i$ pies, portretowane jako poddane opresji jednostki sprzyjające dominującej opcji politycznej, światopoglądowej i militarnej. Każdy ich ruch bacznie obserwowany jest i oceniany przez Szarika, który występuje tu jako rosyjski agent, raz po raz przypominając najważniejszą dyrektywę i ostrzeżenie dowódców Armii Czerwonej: „Ani kroku w tył!”13.

Oba wspomniane teksty dramatyczne przypominają o przemilczeniach, których tak wiele pojawia się we wszystkich opowiadanych historiach rezygnujących z wielości i różnorodności punktów widzenia. Ich przykładem jest przedstawienie przez Pawła Demirskiego jednego z obecnych na scenie czołgistów jako osoby czarnoskórej, a innego jako Żyda. Stereotypy w postrzeganiu grup etnicznych dosadnie podkreślają wypowiedzi Olgierda:

ej ty śmieszny kowalu śląski chodźcie tu na chwilę [...]

czy ja powiedziałem głupi Gruzinie z chorobą weneryczną? [...]

a czy powiedziałem ty czarny

w kurtce ze skaju do dresów sprzedawco

nielegalnych papierosów

który przyczynia się do upadku

budżetu ziemiaństwa? ${ }^{14}$

Poległy w siódmym odcinku serialu pierwszy dowódca załogi Rudego 102 daje szansę Demirskiemu na zaznaczenie także różnic klasowych, których nie zniwelowały nawet lata wojny, okupacji, wygnania i pozorne „braterstwo broni":

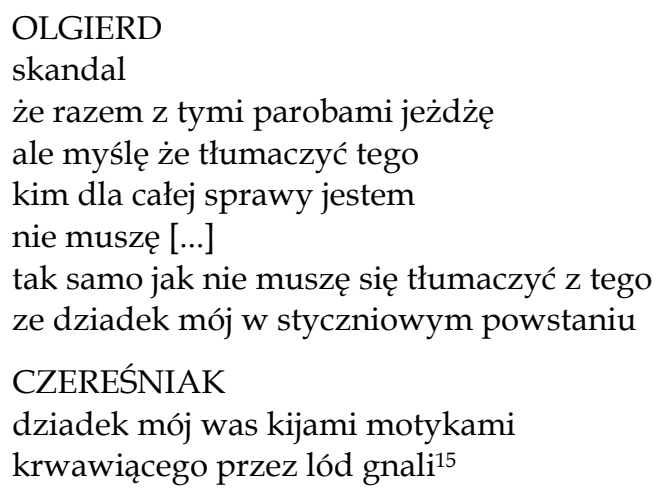

Represja pewnych obszarów pamięci historycznej nierozerwalnie wiąże się także z represją określonych klas i grup - religijnych, narodowych, rasowych których status, identyfikacja geograficzna, a nawet ogólnie rozumiana tożsamość,

\footnotetext{
${ }^{13}$ Ibidem, s. 389-390, w tym i kolejnych cytatach interpunkcja oryginalna.

14 Ibidem, s. 355-356.

${ }^{15}$ Ibidem, s. 362.
} 
zależna jest właśnie od ich obecności w świadectwach przeszłości i we wspomnieniach na jej temat. Teatr dążący do otwarcia dyskursu historycznego przyczynić się może do wydobycia tego, co przez lata ukryte, nagłośnienia tego, co programowo uciszane, wypowiedzenia tego, co przemilczane. Kontekst postkolonialny, którego świadomość ujawniają niektórzy twórcy teatralnych prezentacji, prowokować ich może do podjęcia próby pełnego opisania sytuacji marginalizowanych grup i jednostek. Szczególnie interesujące $\mathrm{w}$ polskiej perspektywie widzenia tych zjawisk są przypadki jednostek bezpośrednio dotkniętych zmieniającym się układem frontów drugiej wojny światowej i wynikających z nich zmian relacji pomiędzy dominującymi i podległymi grupami społecznymi. Należą do nich także wszyscy ci, którzy bezpośrednio doświadczyli zmian władzy i przesunięć granic państwowych w czasie II wojny światowej i zaraz po niej. Dotyczący ich temat, choć ciągle jeszcze nieregularnie i w niewielkiej intensywności, pojawia się w polskiej literaturze i filmie, a także w dramacie i teatrze. Skupię się na dwóch przykładach polemicznej praktyki teatralnej, która przełamuje dominującą w kręgu kultury polskiej (zwłaszcza po roku 1989) narrację mówiącą "językiem ofiar" na temat „wspólnoty niewinnej i dotkliwie doświadczonej” 16 .

Wspominany tu już, wyreżyserowany przez Jana Klatę wrocławski Transfer!, przygotowany został z użyciem wprowadzonej przez niemiecki teatr Rimini Protokoll 17 formuły teatru ekspertów. Metoda ta polega na zaangażowaniu konkretnych osób, np. uczestników jakichś wydarzeń, którzy osobiście, często ze sceny, w obecności publiczności, opowiadają o sobie, własnych przeżyciach i pamiętanej przez siebie historii. Transfer! był rodzajem werbalnej narracji na temat wojennych i powojennych doświadczeń polskich repatriantów z terenów dzisiejszej Ukrainy i przedstawicieli innych narodowości dotkniętych akcją „Wisła”, a także Niemców z Dolnego Śląska i Prus Wschodnich. Prezentowane przez nich wielogłosowe wspomnienia informowały o zmieniających się zależnie od okoliczności politycznych stosunkach i relacjach pomiędzy przedstawicielami różnych nacji. W wypowiedziach postaci występujących w spektaklu często pojawiają się także Żydzi, którzy w scenicznej prezentacji pozostają nieobecnymi, pozbawionymi własnego głosu ofiarami historii. Ich brak przemawia tak dobitnie, że pośród przywoływanych zdarzeń i okoliczności to właśnie dotyczące ich wspomnienia wywoływały najsilniejsze emocje. Doświadczała ich zarówno publiczność, jak i sami uczestnicy spektaklu, których reakcje - jako osób nie będących aktorami, a uczestnikami historycznych wypadków - za każdym razem, kiedy spektakl był wykonywany, wydawały się spontaniczne. Wraz z bezpośrednimi świadkami relacjonującymi zapamiętany przez siebie obraz opisywanych wydarzeń, również widzowie łatwo ulegali atmosferze kolektywnego współodczuwania.

16 Zła pamięć, ed. cit., s. 10.

17 Jedyne opracowanie twórczości teatru Rimini Protokoll to Rimini Protokoll. Na tropie codzienności. Red. M. Dreysse, F. Malzacher. Przeł. M. Borowski, M. Sugiera. Poznań-Kraków 2012. 
Elementem dramaturgicznym łączącym wszystkie pojawiające się w spektaklu wątki była zmiana demograficzna dokonana na Dolnym Śląsku po drugiej wojnie światowej. Wspomnienia osób przesiedlanych ze Wschodu na równych prawach zestawione zostały ze wspomnieniami dotyczącymi deportacji niemieckich mieszkańców Wrocławia i innych „wracających do macierzy” terenów. Pojawiające się na scenie postacie mówią we własnym imieniu, zyskując w oczach widzów - niemożliwy do uzyskania w tradycyjnym teatrze - walor autentyczności. Wiarygodni jako świadkowie, przekonują także jako autorzy spektaklu, choć jego scenariusz mimo tego, że powstał na podstawie ich wspomnień na temat historii, której bezwzględności doświadczyli osobiście - napisany został przez zespół dramaturgów ${ }^{18}$. Polityczną zmienność, podkreślaną zmiennością sposobu edukacji dzieci i młodzieży, najlepiej ukazuje wypowiedź jednego z mężczyzn, który w jednej z pierwszych scen spektaklu mówi:

Mam sześć różnych świadectw. W różnych językach. Przed wojną ukończyłem trzy klasy szkoły powszechnej. Świadectwo po polsku. Raz. Wchodzą Rosjanie. Świadectwo po Rosyjsku. Dwa. Wchodzą Niemcy. Świadectwo po niemiecku i po rosyjsku. Trzy. Po szóstej klasie zapisałem się do tajnego gimnazjum. Świadectwo tajnego nauczania. Cztery. Ponownie wchodzą Rosjanie. Świadectwo po ukraińsku i po polsku. Pięć. Do ósmej klasy nie idę. W 1946 wyjeżdżam i zatrzymuję się w Kluczborku. Świadectwo dojrzałości. Sześć ${ }^{9}$.

Szybko jednak sceniczne opowieści zostają naznaczone piętnem tragedii rozgrywającej się $\mathrm{w}$ obliczu wojny i dążenia do zmian relacji narodowościowych na ziemiach ukraińskich. Jak ujął to kolejny z bohaterów Transferu!, we wrześniu 1939 roku „wszystko się skończyło: plany, marzenia, dobre sąsiedztwo i moje dzieciństwo". Starsza kobieta przywołuje własne wspomnienia:

Jak przyszli Niemcy, Ukraińcy zaczęli mordować, nie wiem dlaczego W okrutny sposób. W dzień był spokój, a w nocy wszystko palili, całe wioski. Tylko łuny było widać. A przecież przed wojną wszystko było dobrze [...]. Coś jakby z polityką zaszło. [...] Zabili księdza, zmasakrowali ciało, a na ścianie napisali „marsz na zachód”. Zaczęliśmy się bać.

Dominuje utrwalony schemat postrzegania wydarzeń dziejowych. I choć to Ukraińcy jawią się jako jednoznacznie negatywne i w narracjach pochodzących od przedstawicieli innych nacji biorących udział $\mathrm{w}$ tej opowieści pozbawiane prawa głosu postaci tej opowieści, wyraźne są w niej także świadectwa udziału Polaków w plądrowaniu żydowskiego majątku na wschodzie. Jednocześnie wskazana zo-

18 Ulrike Dittrich, Dunja Funke, Zbigniew Aleksy i Sebastian Majewski.

19 Wszystkie cytaty ze spektaklu Transfer! pochodzą z jego telewizyjnej rejestracji wykonanej przez TVP Kultura, emisja 16.12.2008. 
staje jednak przywódcza rola żołnierzy niemieckich, którzy dokonywali także egzekucji ludności cywilnej różnych narodowości. Spektakl daje szansę wypowiedzenia się ich dzieciom, które w swoich rodzicach nie chcą dostrzegać katów, a ofiary systemu. Kobieta, która wspomina, że nie mogła znieść głosu Goebbelsa $\mathrm{w}$ czasie radiowych transmisji jego przemówień propagandowych, staje w obronie matki i ojca, niegdyś oddanych sprawie narodowo-socjalistycznej:

Wina czy nie-wina. Ani mój ojciec, ani moja matka nie są winni i dziś wieczorem też tego nie powiem. Oni nie są winni! Żyli w systemie i nic na to nie poradzę. Nie chcę słuchać, że moi rodzice byli nazistami.

Literatura teatralna stwarza wrażenie niezapośredniczonego cytowania słów postaci, a otwarta performatywność tekstu pozwala ukazywać ich działania za pomocą praktyki aktorskiej. Specyficznym przypadkiem scenicznych aktów wykonawczych jest cytowanie słów i wyobrażanie sposobu bycia i działań postaci realnych. Bezpośrednie przytoczenie na scenie wypowiedzi uczestników minionych zdarzeń, ich świadków, a także ofiar; wszystkich tych, których głos nie zawsze jest słyszany przez dominację ustalonej narracji historycznej, to konsekwencja przyznania im prawa do mówienia we własnym imieniu. Wypowiadane słowa stają się świadectwem przeszłości niezależnie od wymowy i stopnia iluzyjności podejmowanych przez aktorów aktów wykonawczych. Szczególny przypadek, w którym teatr zaczyna pełnić formę trybuny dyskursu historycznego, zachodzi wówczas, kiedy na scenie pojawiają się osoby opowiadające o własnych doświadczeniach $\mathrm{w}$ ramach historii powszechnej, relacjonujące prywatny, różniący się od zastanego, punkt widzenia. Ich osobiste wrażenia, przeczucia i zachowana w pamięci świadomość przeszłości staje się $\mathrm{w}$ odbiorze pełnoprawnym dokumentem przeszłości. To przypadek Transferu! - spektaklu oddziałującego z ogromną siłą, chociaż aktorzy nie mają scenicznego obycia i nie próbują nawet kreować wrażenia iluzji ani przydawać atrakcyjności własnej obecności przed widzami.

Drugim przykładem, który chciałbym przywołać w kontekście przesunięcia granic i przesiedleń, jest spektakl na podstawie tekstu Trash Story Magdy Fertacz ${ }^{20}$, wystawiony w czerwcu zeszłego roku w Lubuskim Teatrze Dramatycznym. Jego reżyser, Marcin Liber, sięga do historii Zielonej Góry - miasta swojego urodzenia w lokalnym wspomnieniu losów tamtejszych Niemców w połowie lat czterdziestych znajdując uniwersalny potencjał tragiczny. Akcja rozgrywa się współcześnie, w domu na "ziemiach odzyskanych" zamieszkałym przez córkę powojennego osadnika i jej rodzinę. Na scenie, prócz postaci żyjących obecnie: Matki, Małego czy Wdowy, pojawiają się także duchy - obok ducha Aleksandra, który utopił się przed paroma laty w płynącej za domem rzecze, kiedy odwiedził dom w przerwie służby wojskowej w ogarniętym wojną kraju na Wschodzie (Iraku lub Afganista-

${ }^{20}$ M. Fertacz, Trash Story. „Dialog” 2008, nr 4. 
nie, symbolizujących niespełnione od dziesięcioleci polskie ambicje kolonialne), to także duchy Niemek - kobiet, które mieszkały w okolicy, a w obliczu nadchodzącej Armii Czerwonej same odebrały sobie życie. W pierwowzorze dramatycznym postać z zaświatów była tylko jedna - Urszulka, która w połowie lat czterdziestych została powieszona w stodole przez własną matkę.

W dokonanej przez Libera inscenizacji Trash Story byty duchowe trwają w miejscach swojego życia i śmierci, pomiędzy żywymi, w przestrzeniach, w których doświadczały chwil szczęścia i największej tragedii. Uczestniczą w akcji, łącząc różne poziomy istnienia. Prowadzą rozmowy z żywymi podczas ich sennych wizji, towarzyszą niemieckim turystom, a gdy gaśnie światło, wspomagają domowników ognikami zapalniczek. Chór dziewięciu duchów z przeszłości opowiada historię Ursulki. Mówiące jej tekstem kobiety w podobnych kostiumach, zespołowo odgrywając identyczne emocje, pozostają indywidualnymi, odrębnymi bytami scenicznymi. Rozbicie postaci dziewczynki na dziesięć głosów, z osobną, tragiczną historią stojącą za każdym z nich, sprawdza się znakomicie jako dopełnienie wprowadzonego przez Fertacz efektu dramaturgicznego, co szczególnie sprawdza się $\mathrm{w}$ epilogu, kiedy ukojone dusze Ursulek pojawiają się na scenie w historycznych strojach bamberek, z pięknymi wiankami kolorowych kwiatów na głowach.

Początek jest jednak mroczny i niepokojący. Kiedy publiczność wchodzi do sali teatru, na ekranie zasłaniającym scenę wyświetlane są filmy ukazujące przemarsz oddziałów SA przed Adolfem Hitlerem w mieście podobnym do tego, w którym znajduje się teatr - może to właśnie Zielona Góra? Wizja radości i dumy wiwatujących tłumów nie przysłania współczesnym widzom widma nadciągającej wojny. Kiedy pauza unieruchamia obraz Führera $z$ ręka wzniesiona w rzymskim geście pozdrowienia, dziesięć kobiet mówi o swoich osobistych i zawodowych sukcesach. Każda z nich przed swoim właściwym imieniem - Klarin, Anne, Marthe, Truda - stawia imię Ursulki. Ich opowieści nawiązują do lokalnej, lubuskiej historii, wzbogacając dramaturgicznie tekst Trash Story i nie burząc przy tym spójności dramatu ani nie ograniczając grona jego adresatów. Decyzja dramaturga Michała Pabiana pozwala ukazać jednostkowe wymiary wielkiej historii. Aptekarka, malarka, architekt, farmaceutka, pedagog znaczą kontrast pomiędzy swoim przedwojennym szczęściem i późniejszą tragedią. Mężczyźni w brunatnych koszulach spowodowali, że kolory zniknęły z ulic Grünbergu. Ich żądania odbierały sens pracy wychowawczej, artystycznej, edukacyjnej i ściągnęły katastrofę na miasto:

Piękne było to moje Grünberg, wszędzie widziałam kolory. [...] Nie rozumiem dlaczego nagle przestały interesować ludzi kartki i akwarele, a wszyscy zmuszeni byli do kupowania portretów żołnierzy na tle urzędów, szarych, ponurych, monumentalnych. [...] Było równo, jednakowo i brudno. [...]

Ach, kiedyś byłam szczęśliwa, miałam kochającego męża i wspaniałe córeczki. W naszym Grünberg co roku organizowałam Grünfest - święto warzyw, owoców i plonów. $[\ldots]$ 
Mój świat wali się w momencie buty, brutalności i agresji faszystowskich bojówek. [...] Po wieloletniej pracy z muzyką klasyczną nie mogłam zgodzić się na żołnierskie przyśpiewki. [...]

Chciano bym została pedagogiem miejskim i dbała o faszyzację nauki! [...]

Słyszałyśmy już od dawna, że gdy do miasta wkroczą wojska radzieckie, rozpoczną się wojskowe procesy skierowane wobec ludności cywilnej. ${ }^{21}$

Wszystkie opowieści kończą się słowami, powracającymi niczym dramatyczny leitmotiv: „Była duża stodoła. Pożegnałam się i poszłam”. Nawiązują w ten sposób do wydarzeń z początków roku 1945, kiedy przekroczeniu dawnej granicy Niemiec przez Armię Czerwoną towarzyszyła fala masowych samobójstw miejscowej ludności, przede wszystkim pozostających tam kobiet i dzieci.

Kiedy Ursulki kończą swoje opowieści, wstają i z wyprostowanymi w faszystowskim pozdrowieniu ramionami śpiewają popularny w III Rzeszy marsz Am Adolf Hitler Platz (w Zielonej Górze nazwano tak dawny plac Kolejarza). Wraz z ich wyjściem płótno ekranu unosi się, a publiczność przechodzi na scenę, by zasiąść na przygotowanych dla niej krzesłach. Rozpoczyna się główna część sztuki, której najważniejszym bohaterem nie jest żadna z osób dramatu, a przesycone tragiczną przeszłością miejsce. Stoi $\mathrm{w}$ nim biały dom $\mathrm{z}$ czerwoną dachówką, w którym szczęśliwe chwile dzieciństwa spędzała przed wojną Ursulka. Córka osiedlonych tu Polaków wspomina je całkiem inaczej. Bała się go. Pamięta „lepkie ściany”, w których "ciągle coś [...] skrzypiało”. Dom nieopodal rzeki, podwórko i warzywny ogródek przechowują pamięć. Ziemia przesiąknięta jest tu tragicznymi doświadczeniami jej mieszkańców. Dopóki opowieść Urszulki nie zostanie wysłuchana, jej duch nie znajdzie spokoju i ukojenia.

Dramat i teatr, bardziej bodaj niż inne tradycyjne formy artystycznego wyrazu, pozwalają na stosowanie konwencji prezentującej różnorodne, indywidualne doświadczenia jednostkowe. Na moc oddziaływania formy dramatycznej wpływa wrażenie bezpośredniego wypowiadania się postaci scenicznej lub przytaczania jej słów i powtórzonego ukazywania jej losów w teatralnym wiecznym teraz. Dramat historyczny wykorzystuje tę konwencję, prowadząc do powrotu minionych zdarzeń $\mathrm{w}$ dialogach i działaniach postaci ujętych $\mathrm{w}$ ramę konkretnego czasu i miejsca.

Mam wrażenie, że od kilku lat na scenach polskich teatrów, w dużo większym stopniu, niż na innych polach twórczości artystycznej, toczy się jedna z najbardziej znaczących i wielowątkowych dyskusji na temat historii, zarówno $\mathrm{w}$ wymiarze narodowym, jak i lokalnym. Jej znaczenie wiąże się z obserwacją, że celem nie jest jedynie zamiana treści obowiązujących paradygmatów historycznych, znoszących

${ }^{21}$ Cytaty z fragmentów tekstu sztuki dopisanych na potrzeby Teatru Lubuskiego pochodzą z maszynopisu przygotowanego przez autorkę i dramaturga spektaklu, Michała Fabiana, udostępnionego na potrzeby tego artykułu przez twórców spektaklu. 
obowiązującą wersję przeszłych wydarzeń na korzyść wariantów alternatywnych, a o zmianę ogólnego sposobu postrzegania fenomenu historii, która dotychczas jako opowieść powstająca zgodnie z konwencjami narracyjnymi literatury pięknej (Hayden White22) - wpływała także na indywidualną pamięć. W teatrze, dzięki indywidualizacji punktów widzenia, wywodzące się z prac Maurice's Halbwachsa ${ }^{23}$ pojęcie kolektywnej pamięci kulturowej, które pozwoliło Janowi Assmanowi na zniesienie opozycji pomiędzy pamięcią a historią ${ }^{24}$, zostaje zamienione na pamięć doświadczenia prywatnego. Rozbicie narracji na wiele podmiotów mówiących, nawet jeśli jednostka zdominowana jest przez obowiązującą wersję historii, pozwala jej zachować cechy specyficzne, wyróżniające ją i indywidualizujące jej opowieść.

Typowe formy narracji przyczyniają się do eliminacji wielogłosu, w przypadku klasycznych gatunków dramatycznych jest on natomiast elementem niezbywalnym: warunkiem prowadzącym do powstania węzła dramatycznego i środkiem stwarzającym niejeden konflikt, będący motorem fabularnej zmienności teatralnej prezentacji. Wielogłos, rozproszenie i zakładana przeciwstawność punktów widzenia wpływa na rozmycie jednorodnego, zdominowanego przez obowiązującą reprezentację symboliczną, sposobu postrzegania historii. W ten sposób wrażliwa na głos Innego literatura dramatyczna wprowadza element polemiczny wobec zastanego autorytarnego obrazu przeszłości. Nagłośnienie i ukazanie przemilczanej perspektywy wpływa na punkt widzenia teatralnego widza, odsłaniając przed nim dotychczas nieznane, przemilczane czy wypierane ze świadomości wymiary rzeczywistości. Dramaty tego typu - odkrywając ukryte - kształtują świadomość czasu obecnego poprzez wywoływanie dyskursu na temat dziedzictwa przeszłości.

${ }^{22}$ H. White, Proza historyczna. Red. E. Domańska. Przeł. R. Borysławski et al. Kraków 2009.

${ }_{23}$ Zob.: J. Assmann, Pamięć kulturowa. Pismo, zapamiętywanie i polityczna tożsamość w cywilizacjach starożytnych. Przeł. A. Kryczyńska-Pham. Warszawa 2008, J. Assmann, Kultura pamięci. Przeł. A. Kryczyńska-Pham. W: Pamięć zbiorowa i kulturowa. Wspótczesna perspektywa niemiecka. Red. M. SaryuszWolska. Kraków 2009.

${ }^{24}$ M. Borowski, Nakazana przeszłość. Pamięć a historia w polskim teatrze wspótczesnym. W: Zła pamięć..., op. cit., s. 65-74. 
